\title{
Reflexões sobre a escrita intersemiótica em "A antevéspera", de Olney São Paulo
} Claudio Cledson Novaes

As teorias intersemióticas sobre estéticas de vanguardas dos modernistas aos concretistas são apropriadas nas análises das relações entre escrituras literárias e cinematográficas. Os escritores modernistas buscaram na linguagem cinematográfica um diálogo intersemiótico para inovar a escrita literária. Técnicas do plano, da sequência, do corte, da montagem, do paralelismo e da simultaneidade nas imagens passam ao imaginário da literatura desde os escritores das primeiras décadas do século XX. No sentido oposto e complementar, a literatura modernista está na base da evolução cinematográfica para o discurso moderno, no diálogo intersemiótico entre os cineastas e os escritores modernistas. José Carlos Avellar lembra que nos anos 1960 o movimento do cinema novo dialogou com a literatura, para além da adaptação direta de textos literários, transformando formas de composição de imagens literárias em objetivos formais da linguagem fílmica. Segundo ele,

como nos textos modernistas, passamos a filmar planos mais longos, a movimentar mais livremente a câmera e o gravador, a gravar o som no instante da filmagem, a fotografar em cores, a alterar o tamanho e a proporção do quadro, a trocar o firme e suave passeio da câmera num carrinho pela corrida nervosa e insegura com a câmera na mão. (Avellar, 2007, p. 66).

Aparentemente, os elementos da técnica cinematográfica não corresponderiam em nada aos da escrita literária, numa comparação superficial que visse cada linguagem apenas em sua concretude material - papel ou película, o que a definiria exclusivamente como literária ou fílmica. A análise intersemiótica flagra a semelhança de sentidos nos suportes comunicativos diferentes e torna atual o estudo das relações entre literatura e cinema. Focado nesta problemática, analisamos a obra literária do escritor, mais reconhecido como cineasta, Olney São Paulo, que escreve no âmbito das influências das vanguardas modernistas e concretistas, mobilizando temas da ética local regionalista e também dissonâncias estéticas da memória forjada nas técnicas globais cinematográficas.

A leitura dos dois movimentos de diálogo - da literatura buscando recursos do cinema e deste apoiando-se no texto literário - não significa identificar, no primeiro caso, que esta busca é resumida à citação de temas 
cinematográficos ou de filmes e seus personagens nas narrativas literárias; por outro lado, a literatura no cinema não significa que o diálogo é resumido nas várias formas de adaptações dos textos literários à tela. Para compreender o potencial deste diálogo é preciso perceber na convergência entre as duas linguagens, as singularidades das semelhanças e das diferenças, considerando os mecanismos intersemióticos envolvidos ao mobilizar os aspectos da escritura literária e cinematográfica, perscrutando as condições mediadoras de cada signo e simulacros em repetição, no entanto, sendo original a imagem repetida.

Antoine Compagnon, ao estudar a originalidade da citação, observa, no capítulo intitulado emblematicamente "Mostrar", que a palavra divide o poder de encanto da sua unidade efêmera, passando do estágio em que cada termo não sobrevivia ao instante da enunciação e no qual o discurso criava o próprio objeto, para chegar ao momento em que a palavra compartilha este poder com o discurso visual. Conforme Compagnon, "quando o modelo do discurso torna-se visual, gráfico, secular e técnico, na poética de Simonide e na retórica dos sofistas, inaugura-se a possibilidade da repetição do já dito", com isso, o poder da "palavra viva" não funciona mais como "a influência mágica ou a eficácia imediata da fala inspirada, é o poder leigo da mimésis, da citação que repete, produz e reproduz o discurso do outro"(Compagnon, 2007, p. 77).

A partir desta noção de Compagnon, podemos considerar que o movimento suplementar entre palavra e imagem, da literatura ao cinema e vice-versa, pode ser entendido como a perda da epifania da palavra e a desmistificação da originalidade do verbo. $\mathrm{O}$ texto literário repete temas e personagens clássicos do cinema em novas performances, muitas vezes estilizando a técnica do cinematógrafo; e o cinema repete em infinitas novas imagens os discursos literários sob novo olhar desauratizador da literatura no simulacro radical da imagem-em-movimento, repondo o já dito no suporte discursivo especular, assimilando a subjetividade do discurso literário reapresentada na objetiva da câmera e tornando discursos diferentes inseparáveis intersemioticamente, como diz Walter Benjamin (1994, p. 168), o que se perde ou desaparece "é a autoridade da coisa, seu peso tradicional". O fenômeno comunicativo mais importante desta percepção é a duplicidade dos códigos na unidade de cada linguagem, o que Eisenstein considera a força da conjunção simultânea de detalhes na aparente imagem estática da montagem. Segundo ele, "a montagem tem o significado realista quando os fragmentos isolados produzem, em justaposição, o quadro geral, a síntese do tema. Isto é, a imagem que incorpora o tema"(Eisenstein, 2002, p. 28). 
A operação de escrita no conto de Olney em análise é práxis desta teoria da montagem, ao lançar mão de variadas referências temáticas e de personagens do cinema na conjunção do universo literário em que os componentes audiovisuais são ressignificados na forma de expressão, como diz Eisenstein, fazendo o espectador (leitor) interagir com as imagens na expectativa de compreender os sentidos do narrado, a partir do olhar do narrador. Ou seja, a focalização da forma estética é fundamental para o significado ético do conteúdo. No conto de Olney é possível identificar muitas referências cinematográficas e outras passam despercebidas ao leitor, no entanto os significados cinematográficos retomam outras intenções formais na narrativa literária, mantendo o diálogo com a expressão do cinema, ao interagir com alguns elementos: o tempo narrativo estruturado em planos, o narrador simulando a câmera, ao descrever o cenário, os cortes indicando matizes de cor e tonalidades da luz, além de parágrafos estruturados como marcações de roteiro no conto "A antevéspera":

Pó.

O ascensorista aspira o pó e expira o vácuo.

O elevador desce para o centro da terra que é escuro e negro pó.

Pó em quarto cúbico.

Terceiro.

Alguém dorme no segundo andar, em seu primeiro dia de criação.

Não chegará talvez a dois mil anos de ouro em pó.

Quem?!

A pomba.

A pomba?

Sim. Uma pomba. Translúcida, voejando, volatilizando.

Térreo.

Os ladrilhos, a terra, o pó. (São Paulo, 1969, p. 25)

Temas cinematográficos são sugeridos no conteúdo e na forma da narrativa, internalizando no literário o sentido fílmico. Mas o texto não escapa ao gênero da literatura, pois é publicado para expressão verbal no papel, mesmo que a composição intrínseca da linguagem confirme o simulacro da forma visual cinematográfica na publicação impressa. Apesar das várias referências objetivas e subjetivas do processo fílmico, não se trata da projeção material de filme na tela. A materialidade literária do conto "A antevéspera" confirma o gênero literatura que textualiza diversas técnicas cinematográficas, principalmente o que Julio Plaza analisa, apoiado nas teorias de Eisenstein, como "montagem expressiva", em que o filme se "liberta da linguagem discursiva e lógica", operando na escritura o que, segundo Plaza, "pode ser interpretada como a saturação e migração de 
um código sobre o outro", (Plaza, 2008, p. 139) que é o movimento emblemático das relações intersemióticas nas escrituras e representações.

O contraponto crítico entre as duas linguagens é mais produtivo quando apontamos nesta direção das equivalências transformadas em outros sentidos, como processo de articulação intersemiótica que compartilha os códigos de uma linguagem na outra e descortina novos simulacros e visibilidades nas performances dos mesmos objetos narrados em discursos diferentes. A reconstrução dos sentidos, a partir do mesmo significado, independe da forma explícita ou não do diálogo intersemiótico. À análise interessa discutir a forma de materialização dos objetos narrados em cada linguagem e a ressignificação desses objetos, ao contrário de buscar significados estáticos e idênticos em formas diferentes de enunciados. Ao articular as teorias do signo aos novos aspectos semióticos e às apropriações da crítica concretista, para atualizar as investigações sobre a recepção poética das formas intersemióticas, os estudos de Julio Plaza acionam as estratégias de leitura dos deslocamentos da mimese clássica na representação contemporânea. Para ele, "se as qualidades materiais do signo influem e semantizam as relações com seus sentidos receptores, então os caracteres sensoriais, as formas produtivas e receptivas estão inscritas na materialidade do signo" (id., p. 49).

A interação entre as linguagens da literatura e do cinema no conto de Olney dá-se no nível dos signos e não na superposição da expressividade de cada linguagem isoladamente. O sentido do objeto cinematográfico tem expressão literária e o leitor articula criticamente os intercursos da diversidade sensória, estimulando na leitura do texto narrativo verbal os constructos intersemióticos na narrativa semanticamente imbricada. Estes sistemas de representação cultural pautados nos diálogos intersemióticos são estabelecidos em diversos momentos da literatura brasileira e do cinema nacional, desde o encantamento dos modernistas pela técnica da linguagem cinematográfica, ou pelas peripécias de certos personagens do cinema clássico, ou ainda pela pujança de alguns cineastas, que se tornam temas da narrativa e da poesia modernistas. Um contraponto crítico negativo neste diálogo do cinema com a literatura é quando a hierarquia elege a tradição literária como emblema cultural superior, tomada como forma de valorizar o cinema adaptado do texto literário já consagrado. Por isso, a adaptação cinematográfica do texto literário, no auge do cinema clássico, era considerada melhor ou pior segundo o grau de "fidelidade" do discurso fílmico em relação ao verbal. Neste viés, o enredo da narrativa no cinema era sempre devedor do valor simbólico acumulado pela tradição literária. José Carlos Avellar observa que: 
A relação entre literatura e cinema se realiza no instar da linguagem, bem ali onde se forma o pensamento. Existe porque o cinema, como a literatura, é linguagem. Porque no interior da linguagem (para flagrar o movimento, o acaso, o passar do tempo) inseriu-se a imagem cinematográfica; porque desenvolvemos um outro material para a criação de formas que constroem o pensamento que constrói a linguagem que constrói novos pensamentos: a imagem cinematográfica, não o imediatamente visível nos filmes, mas o processo de invenção deste imediatamente visível. (Avellar, 2007, p. 113)

O desenvolvimento da crítica de cinema, inclusive contando com adesão de reconhecidos críticos da literatura, assimilou parte dos aparatos teóricos literários na abordagem do signo fílmico. Assim, os sistemas críticos do cinema se sofisticam na intenção de flagrar relações intersemióticas entre as duas linguagens, superando os dilemas da crítica tradicional sobre adaptações.

Julio Plaza demonstra um procedimento radical de tradução semiótica na montagem do filme $O$ encouraçado Potemkin, destacando que o diretor tece os sistemas interpenetrados para produzir sentidos intersemióticos na narrativa, através de montagem que obriga, segundo ele, "o espectador a preencher os elos de união entre diferentes planos, como experiência criadora em contraposição à confirmação minética do simples enunciado lógico dos acontecimentos" (Plaza, 2008, p. 142).

O movimento de enunciação para além da lógica narrativa formal responde às novas condições do simulacro literário em diálogo com a técnica de montagem expressiva do cinema. Este processo de criação por colagens de imagens é fundamental na literatura de Olney São Paulo, por exemplo, em "A antevéspera". Esta experiência intersemiótica não é muito frequente em qualidade no conjunto da literatura brasileira, pois muitos casos do cinema adaptado da literatura ou da literatura adaptada dos recursos do cinema têm resultados que não ultrapassam a simples citação intertextual e não operam na percepção do receptor no nível da interdiscursividade, como faz Olney, montando o texto verbal segundo recursos iconográficos. A fragmentação da narrativa no conto, em busca da imagem total, ocorre em semelhança à montagem no cinema, como ela é descrita pelo cineasta russo Serguei Eisenstein em seus escritos sobre a relação entre a palavra e imagem, afirmando que:

é precisamente o princípio da montagem, diferente do da representação, que obriga os próprios espectadores a criar, e o princípio da montagem, através disso, adquire o grande poder de estímulo criativo interior do espectador, que distingue uma obra emocional- 
mente empolgante de uma outra que não vai além da apresentação da informação ou do registro do acontecimento. Examinando esta diferença, descobrimos que o princípio da montagem no cinema é apenas um caso particular de aplicação do princípio da montagem em geral, um princípio que, se entendido plenamente, ultrapassa em muito os limites da colagem de fragmentos de filme. (Eisenstein, 2002, p. 30-1)

Seguindo este princípio, o traço intersemiótico do diálogo com o cinema, no texto literário de Olney São Paulo, forja a linguagem híbrida do escritor que terá seu maior engajamento cultural na arte cinematográfica, a partir dos anos 1960. A nossa opção por verificar a problemática do diálogo entre literatura e cinema na obra de Olney é observar a forma de articulação intersemiótica nas duas linguagens do escritor e cineasta, porque, enquanto escritor, ele pensa literariamente com a técnica do cineasta, ou, pelo menos, do cinéfilo declarado à época em que escrevia a maioria dos seus contos, tentando ser escritor, antes de se tornar diretor de cinema. Por exemplo, "Manhã cinzenta", primeiro conto (ou novela) do livro A antevéspera e o canto do sol, foi adaptado por Olney em seu filme homônimo. Mas antes da forma literária publicada, o texto teve a gestação como roteiro. Esta é a narrativa mais conhecida do autor, onde se estabelece fortemente esta tensão do diálogo intersemiótico, porém, nesta análise, privilegiamos o segundo conto publicado no mesmo livro, "A antevéspera", ainda não estudado nesta perspectiva. Apresenta a mesma estratégia do diálogo entre os referentes literários e cinematográficos, vislumbrando o estilo intersemiótico para além da expressão gramatical colada às citações diretas ou indiretas do cinema; e ainda, para além dos recursos estilísticos alegóricos da linguagem do cinema na escrita literária. No conto "A antevéspera", os recursos sintáticos e semânticos se fundem na composição do estilo da "escrita cinematográfica". Porém, no sentido profundo de reconhecimento da memória afetiva do escritor, que na autoria do conto desvela o cinema como preferência ética e estética, chegando ao maneirismo da escrita cinematográfica no texto verbal, ao instaurar o personagem narrador como simulacro do escritor-cineasta, demarcando traço biográficoficcional marcante do autor Olney São Paulo.

A técnica usada em "A antevéspera" tanto pode mostrar seu texto literário como estilo de vanguarda, quanto pode revelar idiossincrasia estilística do escritor-cineasta. É esta ambiguidade do processo de escrita que desvia o autor do simples "estilo de época", ao desconstruir a noção tradicional de diálogo entre literatura e cinema numa obra de aspectos 
concretistas, conforme os vários recursos iconográficos no conto que simulam ícones do imaginário ocidental:

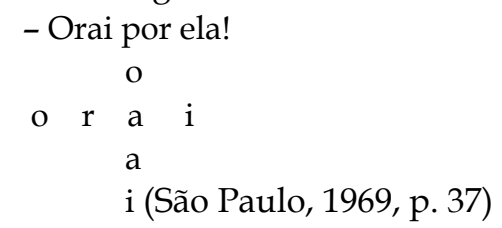

Ou quando a narrativa brinca com sinais gráficos, fazendo simulações de siglas e significados em uma língua estranha: “VIET \& \$ +" (id., p. 44).

"A antevéspera" exercita na forma as marcações de falas dramatizadas e parágrafos sincopados, como no diálogo de personagens do cinema. Mas a percepção deste estilo só terá sentido cinematográfico na exploração crítica do conto literário, o que perfaz o jogo intersemiótico construtivista do signo. A narrativa literária do conto também pode ser lida por leitor desprovido de formação cinematográfica. Desta forma, o que a narrativa perde na leitura, sem as articulações intrínsecas com o cinema na tessitura literária, ganha, na mesma leitura, na perspectiva de escrita imagética, que se estrutura na técnica de montagem do cinema como traço natural do estilo literário do autor, mesmo que a noção de montagem não seja associada diretamente pelo leitor ao procedimento técnico basilar da narrativa no cinema.

O traço da escrita cinematográfica no texto literário de Olney tem o instigante tom "natural", surgindo uma literatura que não é exercício de escrita interessada na expressão racional deste diálogo. É a expressão literária fundada na naturalidade da escritura de estilo híbrido, às vezes, maneirista, do escritor-cineasta. A hibridez dificulta resumir o enredo do conto "A antevéspera", pois as imagens são colagens de cenas que funcionam como sequências do cinema narrativo e do cine-poesia. Os gêneros cinematográficos no texto não definem uma lógica única ao enredo, mas uma composição lírica e dramática de personagens nos cenários, instaurando a visibilidade da literatura cinematográfica e construindo a totalidade do narrado a partir da projeção de fragmentos reais e imaginários.

O início do conto "A antevéspera" remete à imagem simbólica de gênese, que se insinua num jogo de luminosidades imemoriais, imprimindo aos olhos dos leitores tons de luzes e formas cinematográficas, como numa sala escura de cinema na qual se projetam imagens totêmicas de filme literário sobre a gênese trágica do mundo contemporâneo:

Em genuflexo, circunavegando, girando, voltejando o sol e enclausurando a torre de marfim - crivando-a de flexas (sic) e fazendo rebimbalhar os seus sinos dourados em circunflexões de desgraças - o desespero do som e da luz, a desintegração do sol em prisma 
Claudio Cledson Novaes

de concreto armado - a recomposição da terra em seu princípio e a iniciação dos homens em fim. (id., p. 25)

A parte I do conto inicia com esta efusão luminosa que desintegra a noção estética da luz no cinema clássico. Os tons da ficção científica vão ganhando contornos reais e concretos nas sequências seguintes que remontam fragmentos de memórias sombrias e trágicas do contexto histórico. O narrador descreve um elevador que "desce para o centro da terra que é escuro e negro pó", onde "alguém dorme no segundo andar, em seu primeiro dia de criação" e vislumbra a "pomba". "Translúcida, voejando, volatilizando". Quando o foco narrativo chega ao térreo, "uma multidão de homens sisudos, cabisbaixos, longe do céu, pouco a pouco, em cada minuto, em cada metro quadrado de terra, está se transformando em pó". A bilabial " $p$ ", de pomba, sugere uma alternância para a bilabial " $b$ ", de bomba, pois as imagens em flashbacks narrativos desenrolam ao olhar do leitor fatos históricos interagindo na projeção do imaginário literário. Surgem imagens como fotogramas de filmes de poesia calcados na história factual registrada em fotografias que congelam cenas enigmáticas e mostram o significado transcendente dos horrores fotografados à época. $\mathrm{O}$ conto simula o olhar cinematográfico, ao expressar palavras e frases que reconstituem o passado próximo como fotografias distantes e estáticas que a câmera-olho registra na memória em movimento documentário de construção ficcional, tornando o enredo uma alegoria fragmentária da história: "Em Nagasaki, em Hiroshima, em qualquer outro lugar o Paraíso Perdido, as mulheres, as crianças, sobretudo as crianças, tiritavam de frio. Um frio de gelar a espinha, um frio de congelar o óleo ingerido pelos esquimós, um frio de endurecer o som e petrificar o mar" (id., p. 26).

A relação com a fotografia, principalmente enquanto projeção imaginária do real no cinema, que a imagem literária no conto tem sentido para além da simples rememoração de fatos históricos, ou simples simulações do imaginário literário e cinematográfico. $\mathrm{O}$ conto continua a desfilar imagens de velhos filmes ou de cenários documentados nas lentes dos jornais de guerra, configurando emblemas das duas guerras mundiais na efusão da narrativa fragmentada como flechas de luz saídas de projetor cinematográfico. No cenário surge "Marlene vertida de chinesinha" em meio a Pierrot e colombinas, num "carnaval de agitação e de guerras." As personagens sugeridas dos astros das narrativas do cinema clássico alemão e inglês são flagrantes do cinema na citação explícita do conto, completando o significado da escrita literária cinematográfica.

O conto cria tensão no leitor com o diálogo implícito e explícito da narrativa literária com o cinema, através dos nomes dos personagens, dos ato- 
res e das cenas recortadas do imaginário cinematográfico. Mas a presença do cinema está mais na impressão da forma do que na expressão de cenas e nomes na estrutura de totalidade através dos fragmentos, conforme esta citação: "Um navio fora bombardeado no mar, ali pertinho do Edifício Thermidor e quem sabe às cinco horas da tarde, quando Marlene rasgando a sua fantasia de chinesa, atirou-se no mar, porque aquele mesmo mar teimava em levar o seu mandarim para bem longe do bem me quer e dos filmes de Carlitos"(id., p. 29).

O cinema entra no literário via o imaginário de Carlitos, que se torna tema do conto. Mas o personagem citado não é apenas ilustração do enredo, pois a cena tem sentido trágico na narrativa e o lirismo da imagem cinematográfica de Carlitos encena o contraponto trágico da escritura e se torna estrutura da diegética do texto literário: "no mar, os peixes, nas ruas os cadáveres e nos parques: Carlitos lutando contra todas as guerras, brincando com flores, com Edna Purviance e com o amor de Marlene" (id., ibid.).

A primeira parte do conto segue na intersemiose do personagem Carlitos cinematograficamente distante e próximo do enunciado literário. Ao apresentar o imaginário do personagem do cinema interagindo com descrições da narrativa literária deslocada para outros imaginários, Olney São Paulo vai tecendo a crítica da memória presente do narrador: "Carlitos é como a lua, em noite cheia de estrelas: bailando num céu azul, atlanticamente azul" (id., p. 30); ou ainda:

ali perto do Edifício Thermidor segue um homem muito parecido com Carlitos. Usa chapéu-côco, bengala, um bigodinho e o seu fraque já está bastante usado. Se os seus sapatos não são grandes e recurvos como os de Carlitos. É ele o doutor Evandro Machado de Oliveira - uma das raras capacidades jurídicas de uma cidade morta. Todas as noites ele passa por ali, dobra a mesma esquina e entra no Shangri-La, para encontrar-se com a sua amante - que nem de longe se parece com Edna Purviance. (id., ibid.)

O contraponto entre o universo do imaginário do personagem Carlitos e o universo do contista brasileiro e seus personagens típicos, provoca no leitor a desconstrução dos dois imaginários, que passam a dialogar sem hierarquias, tanto entre os personagens típicos das duas inscrições culturais distintas, quanto desloca a hierarquia do imaginário do cinema clássico em relação ao texto literário moderno. Carlitos permanece no conto como alegoria do equilíbrio formal que o autor estabelece entre as forças imaginárias globais do cinema em suas repercussões locais no narrador literário: "Tinha Carlitos uma amante? Não. Carlitos não possuía Dolores. 
A namorada de Carlitos vendia flores para perfumar um gueto imundo em Varsóvia. No gueto de Shangri-La Dolores jamais aparece. Vieram outras. Uma leva de outras tantas para substituí-la, representar as suas exuberantes carnes" (id., ibid.).

A segunda parte do conto inicia a mesma técnica especular, matizando cores na simulação de lentes e filtros sobre a câmera-olho, ao criar a luz da imagem segundo as experimentações da narrativa:

Azul. Verbo Azul.

Se o céu não fosse azul, seria rosa. Rosa, azul, lilás. A tarde seria rosa também. O mundo todo cor de rosa como as sombras do arco-íris.

E róseo o céu, o mar azul conteriam petrificada em sangue a terra de Jesus, o Nazareno.

Além, muito mais além, que haveria?

Uma imensidão de gente apodrecida, enegrecida, entorpecida em Paris, em Nakasaki, no Vaticano e em Israel. (id., p. 33)

O narrador inicia a segunda parte do conto com a profusão cinematográfica de cores e sugestões que marcam a simultaneidade e o paralelismo narrativos da linguagem do cinema vertida na forma literária. $\mathrm{O}$ foco volta-se para o contexto histórico e para as marcas do imaginário do cinema e da história, fazendo o deslocamento entre a versão global da tragédia moderna e os desdobramentos locais da geopolítica mundial. Isto insere no texto a tradição do neorrealismo crítico do cinema. No entanto, a forma de escritura cinematográfica é deslocada por dentro da tradição literária, ao explorar o tempo da escritura na luminosidade dos adjetivos e outros jogos linguísticos e não mais na marca política engajada na forma convencional do realismo socialista da época: "Existe na South América um grande país infestado de comunistas. Eles querem tocar fogo no petróleo e incendiar o mundo da liberdade, deixar a rua escura. (Saem em passeata todos os dias, tirando o desassossego dos vivos.) Urge que se risque um fósforo nos cabelos da anarquia" (id., p. 36). Os traços irônicos funcionam como pastiche de temas políticos e cinematográficos e fundem fragmentos de obras cinematográficas e linguagens verbais dos relatos ficcionais e noticiários oficiais da época.

Na terceira parte do conto desfilam novos personagens da sétima arte em aparente non sense de justaposições de temas. Entretanto, os cortes e montagem restabelecem os sentidos da narrativa literária, construindo o espaço e o tempo da literatura na formulação dos aspectos líricos na epopeia da tragédia humana enfocada no palco de guerras, mas vislumbrando a utopia humanitária na arte literária em diálogo com personagens do cinema: "Não. Não rezarei por uma chinesinha guardada em urna de 
vidro rosa. Não rezarei por Ana, não rezarei por alemães, nem pela alma de Lúcia Bittencourt, a namorada de Rodolfo Valentino" (id., p. 37).

A narrativa do conto "A antevéspera" se estrutura em cinco partes, que vão retomando nas sequências discursivas e poéticas a estratégia de articular imagens da história com o imaginário cinematográfico reconstituídos na forma literária de vanguarda da primeira metade do século XX. Não é difícil, mesmo para o leitor desinteressado nesta reconstituição intersemiótica, conceber na leitura do conto de Olney São Paulo o tempo literário como relatividade da imagem-em-movimento que reconstitui a cronologia em cenas fragmentárias de filmes interligados ao imaginário histórico do século $X X$, num processo de montagem de choque que instaura a tênue possibilidade totalizadora da narrativa moderna. Nesse sentido, o narrador de Olney São Paulo se filia à tradição das vanguardas formalistas em diálogo com as teorias da montagem no cinema, o que abre perspectivas de diálogo com as tradições contemporâneas renovadoras da literatura brasileira, a partir do jogo de memórias ficcionais e reais que serão os pilares estruturadores da narrativa contemporânea, considerando um dos aspectos destacados por Silviano Santiago como índice do narrador pós-moderno, que dramatiza o intercâmbio de experiências para olhar e representar o irrepresentável na narrativa em fragmentos de linguagens e experiências olhadas, observadas e sentidas. Como diz Silviano:

Razão e finalidade do olhar lançado ao outro não se dão à primeira vista, porque se trata de um diálogo-em-literatura (isto é, expresso por palavras) que, paradoxalmente, fica aquém ou além das palavras. A ficção existe para falar da incomunicabilidade de experiências: a experiência do narrador e a do personagem. A incomunicabilidade, no entanto, se recobre pelo tecido de uma relação, relação esta que se define pelo olhar. Uma ponte, feita de palavras, envolve a experiência muda do olhar e torna possível a narrativa. (Santiago, 2002, p. 52)

O espanto diante do incomunicável no texto de Olney, paradoxalmente, narra multiplicidades de olhares e experiências, retomando as funções da câmera no tecido literário "para falar da incomunicabilidade" de certos acontecimentos testemunhados na mídia ficcional ou documental:

Naquele tempo eu desejei Marlene, eu te esperei, mas encontrei apenas Lúcia-menina correndo num sub-way para Hiroshima, onde deixaram eternizar-se, gravada numa parede a sombra de um operário que construía a civilização da paz. Uma imagem de sangue, por todos os séculos, projetada numa imensa parede de cinemascope. (São Paulo, 1969, p. 45) 
Os jogos de signos líricos e trágicos na narrativa de Olney São Paulo criam atmosfera dramática apresentada em forma de memória-cinema, fazendo da escrita a projeção de imagens captadas pelo olhar sensível da ficção que redefine as dimensões espaciais e temporais do mundo real contemporâneo, causando, no conto "A antevéspera", a impressão semelhante à que temos quando assistimos a filmes sobre os universos culturais e históricos das experiências da memória. Como Funes, o memorioso, de Jorge Luis Borges, o conto de Olney recria histórias como uma máquina de lembrar caleidoscopicamente as formas das imagens infinitamente figuradas e interpenetradas como montagens imaginárias.

No cinema, como na literatura moderna, o corte subverte a lógica tradicional da narrativa, transpondo para a forma fragmentária, mas o narrado não deixa de ser um mundo simulado e imagens produzidas, cortadas e projetadas discursivamente. Este constructo é projetado esteticamente no papel ou tela, que reproduzem criticamente as imagens do real na releitura ética da promessa moderna de redenção da humanidade. Após o século XX desfilar em imagens reais e ficcionais do conteúdo e da forma do conto "A antevéspera", como filme de reconstituição histórica, a reflexão trágico-poética do narrador realista converte o modelo melodramático na tradição vanguardista engajada, ao denunciar as catástrofes modernas movidas em nome da humanidade, como poeta trágico: "há uma infindável guerra se desenrolando em tela panorâmica, destruindo milhares de criancinhas e que só poderá ser refreada com uma bomba atômica" (id., p. 45); ou como trágico-poético:

A lua torna-se vermelha. O mundo enegrece, enruboriza-se, embrutece.

Nesta noite, eu te esperei Marlene.

Eu te esperarei, entre sinos de ouro e na sombra da torre de marfim. Eu te esperarei em mar luzililazes. (id., p. 50)

\section{Referências bibliográficas}

AVELLAR, José Carlos (2007). O chão da palavra: cinema e literatura no Brasil. Rio de Janeiro: Rocco/Artemídia.

BENJAMIN, Walter (1994). Obras escolhidas. Magia e técnica, arte e política. São Paulo: Brasiliense.

COMPAGNON, Antoine (2007). O trabalho da citação. Belo Horizonte: Ed. UFMG.

EISENSTEIN, Sergei (2002). O sentido do filme. Rio de Janeiro: Zahar.

PLAZA, Julio (2008). Tradução intersemiótica. São Paulo: Perspectiva. 
SANTIAGO, Silviano (2002). Nas malhas da letra: ensaios. Rio de Janeiro: Rocco. SÃO PAULO, Olney (1969). A antevéspera e o canto do sol: contos e novelas. Rio de Janeiro: José Álvaro Editor.

Recebido em agosto de 2010.

Aprovado para publicação em dezembro de 2010.

resumolabstract

Reflexões sobre a escrita intersemiótica em "A antevéspera", de Olney São Paulo

Claudio Cledson Novaes

Neste artigo, discutimos a singularidade do discurso intersemiótico no estilo da escrita literária do cineasta Olney São Paulo, através da análise do seu conto "A antevéspera".

Palavras-chave: literatura, cinema, intersemiótica, Olney São Paulo

Intersemiotic narrative reflections in "A antivéspera" by Olney São Paulo

Claudio Cledson Novaes

In this paper we discuss the singular intersemiotic narrative in Olney São Paulo's literary style by analyzing his short story "A antevéspera".

Key words: literature, cinema, intersemiotics, Olney São Paulo

Claudio Cledson Novaes - "Reflexões sobre a escrita intersemiótica em "A antevéspera", de Olney São Paulo". Estudos de Literatura Brasileira Contemporânea, n. 37. Brasília, janeiro-junho de 2011, p. 47-59. 